of that proteus which we call public health. If there be anyone who doubts that the best effort and brains are being employed in this beneficent work, he should read this report and learn the truth. It will tell him, not about politics, but solely about the control and relief of suffering and the maintenance of the health of everybody. For that reason all those whose work is recorded or implied in its pages must feel gratified that their efforts have produced, in spite of the difficulties of these times, so much that is positive good and so much, also, that points to even greater achievements in the future.

G. LAPAGE

\section{BRITISH COUNCIL}

\section{ANNUAL REPORT}

T HE report of the British Council for the year ended March 31, 1948, refers to the withdrawal of its activities from Iceland, Switzerland, French North Africa, Bolivia, Ecuador and Paraguay and the closing of institutes and provincial offices in Belgium, the Netherlands, the Argentine, Colombia, Chile and Peru. To meet the reduction in funds for $1948-49$ from $£ 3,500,000$ in $1947-48$ to $£ 3,150,000$, further reductions in services such as books, drama and films are also being made. During the year, however, the educational work of the Council has steadily developed. It has continued to secure or to recommend British candidates for posts in foreign universities, and forty-two posts, mostly professorships and lectureships, are now subsidized and filled by the Council, and of these ten were filled in 1947-48. The Council has also assisted in the recruitment of suitably qualified staff from Britain for British and foreign schools in many countries overseas, and during the year launched a new scheme of bursary awards designed to bring to the United Kingdom persons who would not normally qualify to obtain scholarships but who, being actively engaged in industry or professional work, would benefit from a short stay in Great Britain and from mixing with those of like occupations.

The large volume of scientific bibliographical inquiries and requests for scientific information has made it necessary to amalgamate the science libraries and scientific information services. Assistance was given to the convening bodies of scientific conferences held in the United Kingdom, and a conspectus of current scientific research in Britain has been compiled and is maintained with the co-operation of numerous bodies and by visits of Council staff to university research departments. The publication Monthly Science News has been replaced by the larger journal British Science News, and assistance has been given in placing agricultural scholars of the Council and in arranging tours for some fifty agricultural visitors. The collection of seed samples from a large number of countries was organised at the request of various research stations, and advice and assistance given to 103 private students from ten countries and to 32 engineers and technicians from thirteen countries on visits to Great Britain. The medical library and information service has expanded considerably, most of the 284 books added being received for review in the British Medical Bulletin, while 310 copies of the monthly list of new British medical publications are eirculated to libraries and institutions abroad.
Programmes of work were arranged for more than forty overseas medical graduates holding British Council scholarships, and the Council is also arranging programmes or accommodation for most of the 'fellows' appointed by the World Health Organisation who elected or were advised to study in Britain. The Council's organisation for receiving visitors was increasingly used by Government departments, overseas Governments, universities and professional societies. Besides the 599 who came as the Council's guests, forty per cent of whom were concerned with science, medicine, agriculture and engineering, 306 who came without financial assistance from the Council had programmes arranged for them. The Council also financed a limited number of delegates to scientific conferences and cultural events, and was also invited by several universities to assist recruitment for their summer schools. The Council took the initiative in convening a committee representing British universities to discuss the possibility of organising a series of summer schools in 1948, designed particularly for American students. The scheme involves a total of 700 students, for nearly 200 of whom from overseas the Council has accepted responsibility.

Reports on activities overseas are considerably curtailed in comparison with previous reports and contain little reference to scientific activities except in Finland, Italy, Poland and Brazil. The slightness of the accounts of the scientific activities of the Council constitutes one of the chief criticisms of the report, although the figures quoted for exchange of students and the like do not suggest that science is not well represented in the Council's activities, or support the impression that might be derived from other passages of the report that the Council is becoming increasingly an instrument of political warfare.

It is perhaps natural that, in view of the searching examination to which the activities of the Council were subjected by the Select Committee on Estimates in a report published last April, some space should be given to comment on the Select Committee's report. While satisfied that the evidence indicated that the Council is regarded as outside politics and that its work is not associated with propaganda or the political feeling of the day, the Select Committee directed attention to the need for introducing an improved permanent service, and questioned the necessity for so heavy a staff at headquarters. Without going elosely into the important question of recruitment, the report indicates that the British Council itself leans towards the view of the Select Committee that Civil Service standards should be applicable in recruiting the bulk of its staff. No agreement has yet been reached, however, on the question of the grades and conditions of service which will ensure the maintenance of efficiency everywhere and adequate representation overseas, nor does the fundamental question appear to have been considered whether the service of the Council should constitute a closed service or whether its staff should comprise mainly those seconded for fairly short periods and then returning to academic life or their normal occupation. The Council hopes for some reduction in staff as a result of careful overhaul of establishments at headquarters, but fears that the financial savings will be absorbed by overdue improvements in staff conditions. Staff questions may not figure so prominently in future reports, but whether they do or not, the report might reasonably be expected to provide fuller public explanation as to how and by whom the plans for our cultural strategy are prepared. 